\title{
DETERMINATION OF THE RATE OF SNOW ACGUMULATION AT THE POLE OF RELATIVE INAGCESSIBILITY, EASTERN ANTARCTICA: A COMPARISON OF GLACIOLOGICAL AND ISOTOPIC METHODS
}

\author{
By E. Picciotto, * R. Cameron, \\ (Institute of Polar Studies, Ohio State University, Columbus, Ohio $43^{2}$ Io, U.S.A.)
}

\section{G. Crozaz, S. Deutsch ${ }^{\dagger}$ and S. Wilgain $\dagger$}

(Service de Géologie et Géochimie Nucléaires, Université Libre de Bruxelles, Bruxelles, Belgium)

Abstract. The rate of snow accumulation has been measured at the U.S.S.R. station situated at the Pole of Relative Inaccessibility (eastern Antarctic plateau). Five independent methods were used. The results, expressed in $\mathrm{g} \mathrm{cm}^{-2}$ year ${ }^{-1}$, are as follows:

(1) Accumulation-stake measurements show an accumulation of $3.1 \pm 0.5$ in 1965 . A maximum value of 3.6 for the 6-year interval $1959-65$ is derived from snow-thickness measurements.

(2) Firn stratigraphy was found difficult to interpret in terms of annual layers. An upper limit of 12 $\mathrm{g} \mathrm{cm}^{-2}$ year $^{-1}$ is suggested.

(3) ${ }^{18} \mathrm{O} /{ }^{16} \mathrm{O}$ ratios were measured along the upper $235 \mathrm{~cm}$. Assuming that each maximum in the isotope profile corresponds to a summer season, the accumulation would be $8.6 \pm 0.9$.

(4) Gross $\beta$ radioactivity as a function of depth was measured on three firn sections. The 1955 radioactive fall-out horizon is clearly marked, enabling the derivation of an average accumulation of $3.0 \pm 0.1$.

(5) The average accumulation over the last 80 years, derived from the ${ }^{210} \mathrm{~Pb}$ distribution with depth, is $3 \cdot \mathrm{I} \pm 0.3$.

A multi-annual average accumulation rate of $(3.0 \pm 0.3)$ is thus firmly established, as well as the validity of both the ${ }^{210} \mathrm{~Pb}$ method and the 1955 radioactive fall-out horizon method. Stratigraphic studies lead to uncertain results. Oxygen isotope variations give accumulation values which are too high by a factor of two at least.

Accumulation values of the same order of magnitude $(2.8 \pm 0.2)$ were derived from radioactive fall-out measurements at the U.S. "Plateau" station.

RÉsumé. Détermination du taux d'accumulation de neige au Pôle d'Inaccessibilité, Antarctique oriental: Comparaison des méthodes glaciologiques et isotopiques. Le taux d'accumulation de neige a été mesuré à la station U.R.S.S. du Pôle d'Inaccessibilité Relative (Antarctique oriental). Cinq méthodes indépendantes ont été appliquées. Les résultats, en $\mathrm{g} \mathrm{cm}^{-2}$ an ${ }^{-1}$ sont les suivants:

(1) Des mesures de balises, une accumulation de $3, \mathrm{I} \pm 0,5$ a été déduite pour $\mathrm{I}_{9} 65$. Des mesures d'épaisseur de neige montrent que la valeur maximum, pour l'intervalle de 6 ans $1959-65$, est de 3,6 .

(2) La stratigraphie du névé est difficilement interprétable en couches annuelles. Une limite supérieure de $12 \mathrm{~g} \mathrm{~cm}^{-2} \mathrm{an}^{-1}$ est indiquée.

(3) Les rapports ${ }^{18} \mathrm{O} /{ }^{16} \mathrm{O}$ ont été mesurés sur une carotte de $235 \mathrm{~cm}$ de profondeur. En supposant que chaque maximum du profil isotopique corresponde à une saison d'été, l'accumulation serait de $8,6 \pm 0,9$.

(4) L'activité $\beta$ totale en fonction de la profondeur a été mesurée sur trois sections de névé. L'horizon de I 955 de retombées radioactives y apparaît clairement. Il permet d'évaluer une accumulation moyenne de $3,0 \pm 0, \mathrm{I}$.

(5) L'accumulation moyenne des 80 dernières années, déduite de la distribution du ${ }^{210} \mathrm{~Pb}$ en profondeur est $3, \mathrm{I} \pm 0,3$.

Un taux moyen d'accumulation de $(3,0 \pm 0,3)$ portant sur plusieurs années est ainsi établi; la validité des méthodes du ${ }^{210} \mathrm{~Pb}$ et de l'horizon 1955 de retombées radioactives est également confirmée. Les études stratigraphiques aboutissent à des résultats incertains. Les variations des isotopes de l'oxygène donnent un taux d'accumulation trop élevé d'un facteur deux au moins.

Des valeurs d'accumulation du même ordre de grandeur $(2,8 \pm 0,2)$ ont été obtenues à partir de mesures de retombées radioactives, à la station U.S.A. de "Plateau".

Zusammenfassung. Bestimmung der Schneeakkumulation am Pol der Unzugänglichkeit, Ost-Antarktika: Ein Vergleich glaziologischer und isotopischer Methoden. Die Schneeakkumulation wurde an der russischen Station am Pol der Unzugänglichkeit (ostantarktisches Plateau) gemessen. Es wurden fünf unabhängige Methoden angewandt. Die Ergebnisse, ausgedrückt in $\mathrm{g} \mathrm{cm}^{-2} \mathrm{a}^{-1}$, sind die folgenden:

* On leave from Université Libre de Bruxelles, Bruxelles, Belgium.

$\dagger$ Institut Interuniversitaire des Sciences Nucléaires, Belgium. 
(1) Messungen an Akkumulationspegeln zeigen 1965 einen Auftrag von 3, $1 \pm 0,5$. Ein Maximalwert von 3,6 für das 6-Jahre-Intervall I $959-65_{5}$ ergibt sich aus Messungen der Schneedicke.

(2) Es war schwierig, die Firnstratigraphie nach Jahresschichten zu interpretieren. Als Maximalwert werden $12 \mathrm{~g} \mathrm{~cm}^{-2} \mathrm{a}^{-1}$ vermutet.

(3) Das Verhältnis ${ }^{18} \mathrm{O} /{ }^{16} \mathrm{O}$ wurde in den oberen $235 \mathrm{~cm}$ gemessen. Vorausgesetzt, dass jedes Maximum im isotopischen Profil einem Sommer entspricht, würde die Akkumulation 8,6 $\pm 0,9$ betragen.

(4) Eine grobe Messung der $\beta$-Radioaktivität als Funktion der Tiefe wurde in drei Firnproben vorgenommen. Der Horizont radioaktiven Niederschlags von 1955 konnte eindeutig festgelegt werden und ermöglichte die Bestimmung einer mittleren Akkumulation von $3,0 \pm 0, \mathrm{r}$.

(5) Die durchschnittliche Akkumulation der letzten 8o Jahre, abgeleitet aus der Tiefenverteilung von ${ }^{210} \mathrm{~Pb}$, ergibt $3, \mathrm{I} \pm 0,3$.

Mit Sicherheit lässt sich so eine vieljährige mittlere Auftragsrate von $3,0 \pm 0,3$ feststellen; zugleich erweist sich die Gültigkeit der ${ }^{2}{ }^{2} \mathrm{~Pb}-$ Methode und der Bestimmung aus dem radioaktiven Horizont von 1955 . Stratigraphische Untersuchungen führen zu unsicheren Resultaten. Das Verhältnis der Sauerstoffisotope liefert Akkumulationswerte, die mindestens um den Faktor $2 \mathrm{zu}$ hoch sind.

Akkumulationswerte derselben Grössenordnung $(2,8 \pm 0,2)$ ergaben sich aus Messungen des radioaktiven Niederschlages an der US-"Plateau"-Station.

\section{INTRODUCTION}

In the course of the last decade, several methods have been developed for dating glacier ice or firn and for estimating snow-accumulation rates, by means of stable or radioactive isotope measurements. These methods are at various stages of development, some of them being applicable on a routine basis, others being mere suggestions.

The polar regions have provided the best field of application. Because of the absence of melting and homogenization of the snow after its deposition, the results are generally simpler to interpret. On the other hand, it is on the polar ice sheets that the isotopic methods are mostly needed, on account of the scarcity of permanent stations and of the difficulties involved in the interpretation of the firn stratigraphy.

Such measurements were included in the glaciological program of the South Pole-Queen Maud Land traverse (QMLT), a major oversnow traverse project in eastern Antarctica sponsored by the U.S. Antarctic Research Program. The general plan is to investigate the sector between the Greenwich Meridian and long. 40 $0^{\circ}$. in four summer traverses along a zig-zag route starting from the South Pole (Fig. I). The first two legs were completed during the summer seasons $1964-65$ and $1965-66$. In addition to the conventional pit-stratigraphy studies, firn samples were collected at each glaciological station, approximately $50 \mathrm{~km}$ apart, in view of various geochemical investigations (including accumulation-rate estimates) by means of the following methods:

i. Oxygen-isotope ratio variations.

ii. Radioactive fall-out horizon from nuclear bomb tests.

iii. ${ }^{210} \mathrm{~Pb}$ radioactive decay.

Similar investigations have already been conducted at the South Pole, yielding consistent accumulation-rate values around $7 \mathrm{~g} \mathrm{~cm}^{-2}$ year $^{-1}$ (Picciotto and others, 1964; Wilgain and others, I965; Epstein and others, I965) in good agreement with the value derived from stratigraphy studies (Giovinetto, I960; Gow, I965) and surface measurements.

Application of these methods on the eastern Polar Plateau requires small-size samples, not at a depth greater than $\mathrm{I}$ o $\mathrm{m}$ and easily obtainable with standard hand-drilling equipment.

The detailed results for the traverse will be published elsewhere. We intend to report here, mainly as a case study, the results obtained at the Pole of Relative Inaccessibility, one of the most important stations because of its geographic location.

The investigations reported here were carried out in the vicinity of the Soviet station at the Pole of Relative Inaccessibility, situated in the farthest inland and the highest and coldest zone of the Antarctic Polar Plateau, at lat. $82^{\circ} \mathrm{o} 7^{\prime}$ S., long. $55^{\circ} \mathrm{o} 6^{\prime} \mathrm{E}$. at an elevation of $37 \mathrm{r} 8 \mathrm{~m}$.

The mean annual temperature, measured by the firn temperature at the depth of $25 \mathrm{~m}$, is $-57^{\circ} \mathrm{C}$. Prevailing winds are from the north-west to north-east sector. 


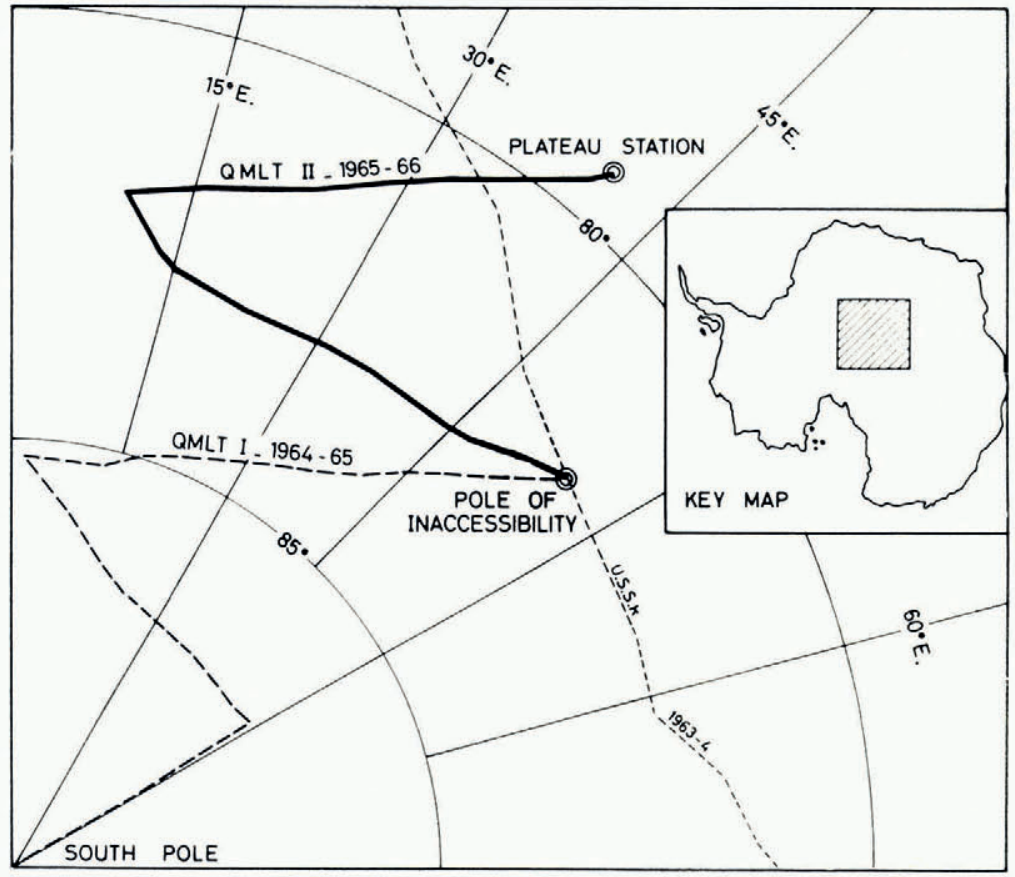

Fig. 1. Route of the Queen Maud Land traverse
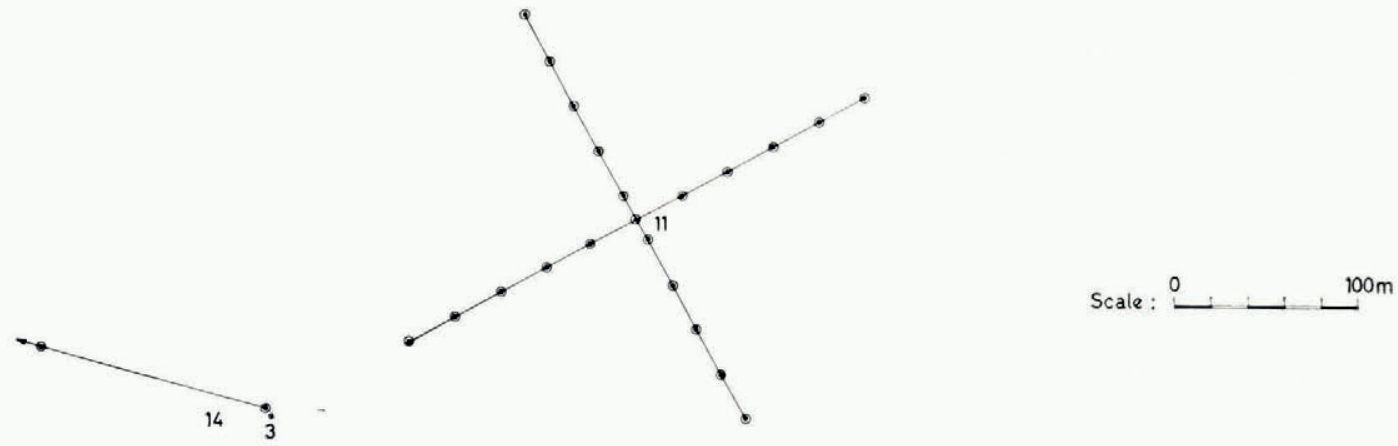

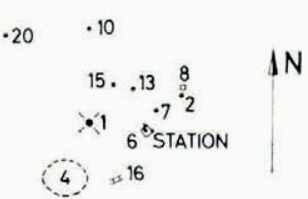

$$
\begin{aligned}
& (5)^{9}=12
\end{aligned}
$$

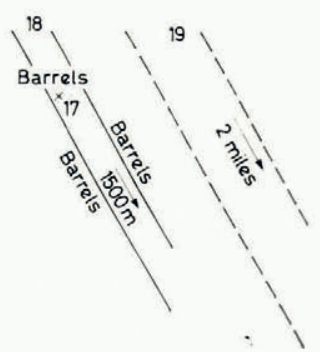

Fig. 2. Map of the U.S.S.R. station at the Pole of Inaccessibility (map data from D. J. Elvers). Points of intcrest for the present work are:
2. Anemometer mast (USSR r958).
3. Pit No. 2, $6 \mathrm{~m}$ deep (QMLT II).
8. Meteorology shelter (USSR 1958).
6. Station building (USSR).
II. Accumulation stake network (OMLT I).
I4. Accumulation stake line (QMLT II). 
The station was established on 14 December $195^{8}$ by a Soviet oversnow traverse from Mirny (Kapitza, I964), and it includes a small barrack hut surrounded by various scientific equipment (see Fig. 2).

It was occupied during four short summer periods:

I 4-26 December i $95^{8}$ (U.S.S.R. traverse from Mirny).

I-6 February i964 (U.S.S.R. Vostok-Molodezhnaya traverse).

27 January-2 February ${ }^{965}$ (U.S. Queen Maud Land traverse, part I).

22 November-1 5 December ${ }_{96} 6$ (U.S. Queen Maud Land traverse, part II).

During the two stays of the Queen Maud Land traverse party at the station, sampling of firn for geochemical studies as well as pit studies and accumulation-stake measurements were carried out by two of us (E.P. and R.C.) with the assistance of Robert Behling and Olav Orrheim.

Three pits were excavated for that purpose:

Pit No. I, 2 m deep, excavated on 28 January $1965,200 \mathrm{~m}$ north of the station.

Pit No. 2, $6 \mathrm{~m}$ deep, excavated in December $1965,500 \mathrm{~m}$ north-west of the station (point 3 of Figure 2).

Pit No. 3, 2 m deep, excavated in December 1965 at about $1500 \mathrm{~m}$ north-west of the station on the new stake line.

\section{Surface Measurements}

Time interval December 1958-January 1965

Near the station, a meteorological study area was laid out in December 1958 and the anemometer mast and the instrument shelter remained from this installation. Small snow pits were excavated at these points, in order to reach the December 1958 surface. Using a measured density (average from the surface to a depth of $60 \mathrm{~cm}$ ) of $0.348 \mathrm{~g} \mathrm{~cm}^{-3}$ and 14 December $195^{8}$ to $3^{\circ}$ January 1965 as the time interval (just over 6 years), the accumulation recorded is as shown in Table $I$.

\section{Table I. Snow Accumulation Recorded at the Meteorological Shelter for a 6-year Period}

(December 1958-January 1965)

$\begin{array}{lccc} & \begin{array}{c}\text { Snow } \\ \mathrm{cm}\end{array} & \begin{array}{c}\text { Water } \\ \mathrm{cm}\end{array} & \begin{array}{c}\text { Annual } \\ \text { accumulation } \\ \mathrm{g} \mathrm{cm}^{-2} \text { year }^{-1}\end{array} \\ \text { Anemometer mast (base plate) } & 63 & 2 \mathrm{I} .9 & 3.6 \\ \text { Instrument shelter (left rear leg) } & 60 & 20.9 & 3.4 \\ \text { Instrument shelter (bottom of steps) } & 66 & 22.9 & 3.7 \\ \quad \text { Average } & 63 & 21.9 & 3.6\end{array}$

The value of $3.6 \mathrm{~g} \mathrm{~cm}^{-2}$ year-1 $^{-1}$ must be considered as an upper limit because of the possibility of drift-snow accumulation due to the vicinity of the station.

Time interval Fanuary-December 1965

A network of accumulation stakes was set out on 30 January r 965 . It consisted of 19 bamboo poles marked with a saw cut $150 \mathrm{~cm}$ above the snow surface (see Fig. 2).

The stakes were re-measured twice: on 23 November and 14 December 1965. The results are given in Table II.

The mean accumulation of snow between 30 January and $1_{4}$ December ${ }_{96} 65$ (o.87 I year) was $8.9 \mathrm{~cm}$, with a standard deviation on the mean of $\pm \mathrm{r} .4 \mathrm{~cm}$. 
Table II. Snow Accumulation (cm) Measured at the Cameron Stake Network (erected 30 January 1965 )

\begin{tabular}{|c|c|}
\hline $\begin{array}{l}\text { Stake } \\
\text { number }\end{array}$ & $\begin{array}{c}\text { Accumulation } \\
\text { 3o January-23 November } \\
\text { Ig65 }\end{array}$ \\
\hline I & 1.5 \\
\hline 2 & -0.2 \\
\hline 3 & 4.0 \\
\hline 4 & 1.5 \\
\hline $\begin{array}{l}5 \\
6\end{array}$ & $\begin{array}{l}26.0 \\
20.5\end{array}$ \\
\hline 7 & $\begin{array}{l}20.5 \\
19.2\end{array}$ \\
\hline 8 & 6.6 \\
\hline 9 & I0.0 \\
\hline IO & I0.0 \\
\hline I I & I I .4 \\
\hline 12 & 3.0 \\
\hline 13 & 7.8 \\
\hline 14 & 20.0 \\
\hline 15 & $3 \cdot 5$ \\
\hline 16 & 7.0 \\
\hline I 7 & 8.2 \\
\hline I 8 & - \\
\hline I9 & $7 \cdot 5$ \\
\hline 20 & 5.0 \\
\hline $2 \mathrm{I}$ & 4.0 \\
\hline Average & 8.8 \\
\hline
\end{tabular}

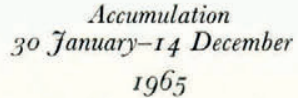

2.0

I.9

$4 \cdot 4$
1.5

1.5
23.6

20.0

18.0
8.8

10.7

10.0

12. I

3.0

8.1
18.2

4.2

$7 \cdot 3$

8.5

$7 \cdot 5$

4.5

4.2

8.9

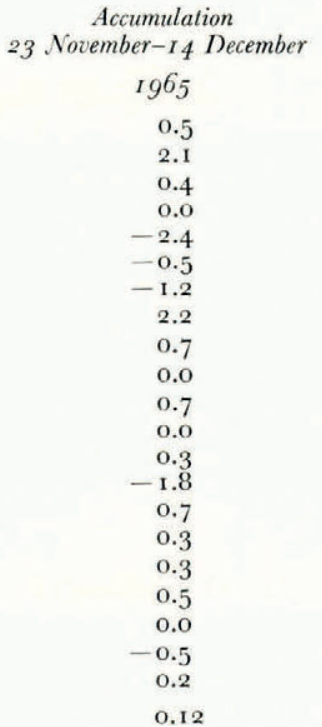

Assuming, by analogy with the South Pole data (Giovinetto and Schwerdtfeger, I966; private communication from L. Aldaz), that the monthly increment is nearly constant throughout the year and using a value of $0.33 \mathrm{~g} \mathrm{~cm}^{-3}$ for the density of snow at the surface, the rate of annual accumulation is:

$$
\text { I0.2 } \pm \mathrm{r} .6 \mathrm{~cm} \text { of snow or } 3 . \mathrm{I} \pm 0.5 \mathrm{~g} \mathrm{~cm}^{-2} \text { year }^{-1} \text {. }
$$

\section{Firn Stratigraphy}

The estimation of snow-accumulation rates from firn-stratigraphy studies relies upon the identification of annual layers. In Antarctica, since the first studies of Schytt (1958) on the Maudheim Ice Shelf, a considerable amount of work has been done to define criteria for annual layering of firn in various parts of the ice sheet. Basic studies at central eastern Antarctic stations were carried out by Giovinetto (1960) and Gow (1965) at the South Pole and by Kotlyakov (I96r).

At the South Pole, according to Gow's (1965) and to our own unpublished observations in pits dug alongside accumulation stakes, a single depth-hoar layer is generally formed every year. Deviations from this rule have been observed; nevertheless, the number of depth-hoar layers is a fair approximation of the number of years. This conclusion is also substantiated by results obtained by geochemical methods (Picciotto and others, r964; Wilgain and others, r965). Giovinetto's ( 1960 ) observations show that the annual stratification is still visible at depths up to $26 \mathrm{~m}$.

The main features observed at the Pole of Inaccessibility are:

In the first $3 \mathrm{~m}$ from the surface, the firn was relatively loose and of low density, with uniform and continuous layering. It was composed essentially of massive polyhedral grains, except in the upper few centimeters where the shape and size of the original snow crystals could still be recognized.

A conspicuous feature was the rapid increase in grain-size with depth, associated with a progressive obliteration of the layered structure. 
Besides abrupt changes in grain-size or in hardness, the layered appearance resulted mainly from the following features intercalated at rather irregular intervals in the firn sequence:

i. Depth-hoar layers, from 2 to $20 \mathrm{~mm}$ thick, composed of an extremely loose aggregate of elongated and cup-shaped crystals.

ii. Iced crusts, 0.5 to $1.0 \mathrm{~mm}$ thick, generally associated with a depth-hoar layer.

iii. Thin ( 0.2 to $0.5 \mathrm{~mm}$ ) but continuous layers of hardened bonded grains.

iv. Very hard, dense and fine-grained layers. They were generally continuous but with variable thickness ranging from 0.5 to $15.0 \mathrm{~cm}$.

Typical densities and grain-sizes are as follows:

fine-grained surface layer

medium-grained, soft

coarse-grained, medium hard to soft

very coarse-grained, loose

very hard, fine-grained

very loose depth-hoar

$\begin{array}{cc}\begin{array}{c}\text { Density } \\ \mathrm{g} \mathrm{cm}^{-3}\end{array} & \begin{array}{c}\text { Grain-size } \\ \mathrm{mm}\end{array} \\ 0.33 & 0.3 \text { to } 0.7 \\ 0.35 & \text { I to } 2 \\ 0.35 & 2 \text { to } 5 \\ 0.32 & 5 \text { to } 20 \\ 0.52 & 0.3 \text { to } 0.5 \\ 0.20 & \text { I to } \mathrm{I} 0\end{array}$

The stratigraphic sequences in pits Nos. I and 2 are sketched in Figure 4. They are very difficult to interpret in terms of annual layers. The main difficulty arises from the rapid fading away of the structures with depth. On the other hand, where the layering is still well marked by crusts, depth-hoar layers, variations in grain-size or in hardness, we know little for certain about the origin of these features nor their relationship with annual periodicity.

Owing to the differences in the firn properties at both locations, the criteria for annual layering successfully developed at the South Pole seem no longer applicable at the Pole of Inaccessibility. In fact, we are unable to give here any definite interpretation of the stratigraphy in terms of annual accumulation. A plausible minimum estimate of the numbers of years represented in the profiles in Figure 4 would be given by the number of well-developed depth-hoar layers (marked by black triangles). The resulting upper limits for the annual accumulation rates, using a mean density from the surface to $2 \mathrm{~m} \mathrm{of} 0.366 \mathrm{~g} \mathrm{~cm}^{-3}$, are:

$$
\begin{aligned}
& \text { pit No. } \mathrm{I}<8 . \mathrm{I} \mathrm{g} \mathrm{cm}^{-2} \text { year }^{-1} \text {, } \\
& \text { pit No. } 2<\mathrm{I} 2.2 \mathrm{~g} \mathrm{~cm}^{-2} \text { year }^{-1} \text {. }
\end{aligned}
$$

If we make the improbable assumption that each visible feature or discontinuity in the firn profiles (marked by open triangles in Figure 4) corresponds to a year, the resulting accumulation rates would be:

$$
\begin{array}{ll}
\text { pit No. I } & 4.1 \mathrm{~g} \mathrm{~cm}^{-2} \text { year }^{-1} \text {, } \\
\text { pit No. } 2 & 2.9 \mathrm{~g} \mathrm{~cm}^{-2} \text { year }^{-1} \text {. }
\end{array}
$$

\section{OXYGEN ISOTOPE VARIATIONS}

The measurement of snow-accumulation rates by means of oxygen- or hydrogen-isotope ratio variations in firn and ice (Dansgaard, r954; Epstein, r956) is based on the fact that these ratios are a function, among other factors, of the temperature at which the snow has condensed. The lower the temperature, the lower the ${ }^{18} \mathrm{O} /{ }^{16} \mathrm{O}$ and $\mathrm{D} / \mathrm{H}$ ratios $($ Epstein and Mayeda, I953; Dansgaard, I954; Botter and others, I960; Picciotto and others, I960; Lorius, I96r ; Dansgaard, r 964). Thus, at a given location, it is possible to distinguish snow precipitated in winter from snow precipitated in summer (Gonfiantini and Picciotto, I959; Epstein and others, 1963; Friedman and others, 1964).

As long as neither the original sequence of deposition of precipitation nor the isotopic compositions are altered, the seasonal periodicity in the firn layers will be reflected by periodic 
changes of the stable isotope ratios as a function of the depth, each period corresponding on average to a $\mathrm{I}$ year interval.

Accumulation rates derived from stable isotope variations were found to be in good agreement with those obtained by pit stratigraphy and stake measurements in various parts of the Greenland ice sheet (Epstein and Sharp, I959; Benson, I962; Langway, I965, p. 84I 28), even in deep ice where layering was no longer visible. In Antarctica, consistent results were obtained on the east coast (Gonfiantini and others, i963; Lorius, r963). An earlier suggestion by Epstein and others ( 1963 ) that, at various locations in western Antarctica and at the South Pole, accumulation values derived from ${ }^{8} \mathrm{O} /{ }^{16} \mathrm{O}$ variations were systematically higher than values derived from pit stratigraphy, seems no longer tenable. At the South Pole, further isotope measurements made on carefully collected and statistically significant samples have given reliable accumulation values (Epstein and others, I965; Wilgain and others, I965).

To carry out oxygen-isotope ratio measurements, firn samples were collected at the Pole of Inaccessibility, along a $235 \mathrm{~cm}$ vertical profile in pit No. I in January 1965.

Two I $\mathrm{m}$ long cardboard tubes, $8 \mathrm{~cm}$ in diameter, were pushed down vertically in the firn.

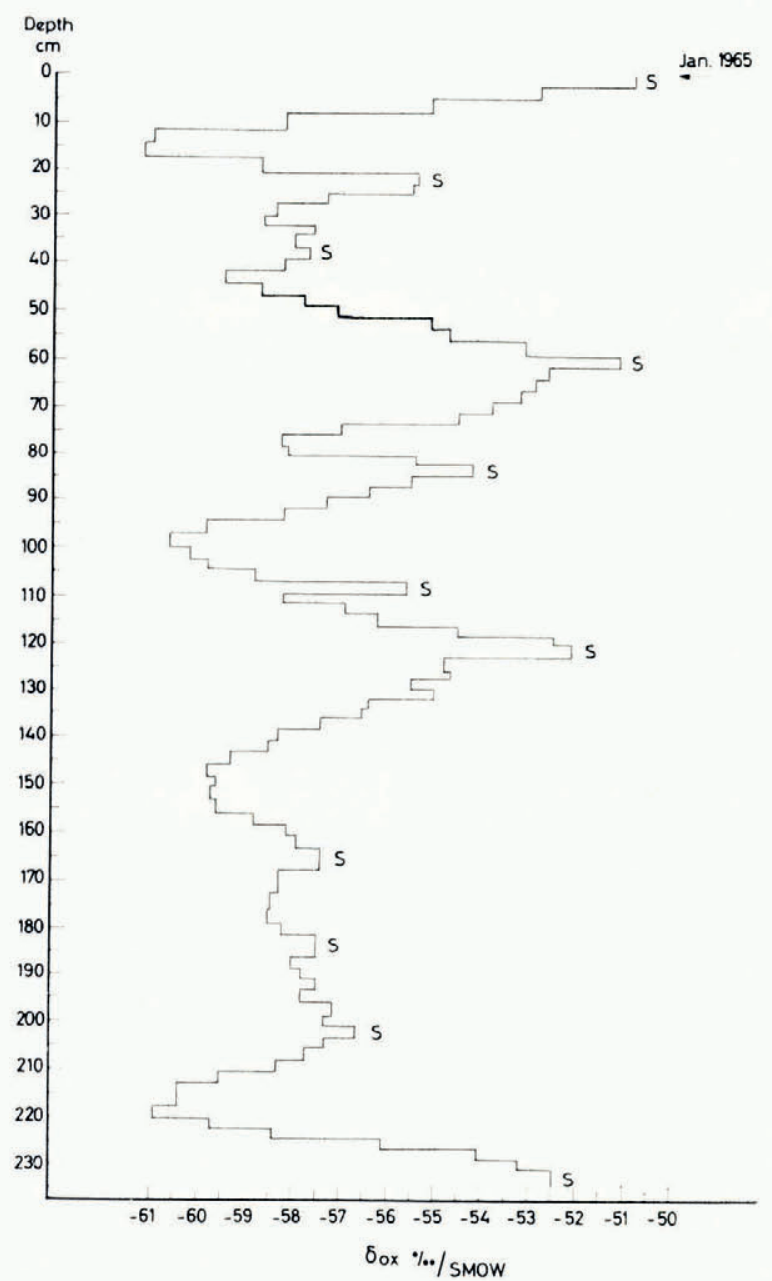

Fig. 3. Oxygen isotope ratio versus depth in pit No. I. Presumed summer maxima are marked "s" 
This procedure resulted in an appreciable compaction of the order of I $_{5}$ per cent. The tubes were stored well below freezing point.

The ${ }^{18} \mathrm{O} /{ }^{16} \mathrm{O}$ ratios of the melted samples were measured following procedures similar to those described by Epstein and Mayeda (1953). The results are expressed in the usual way in

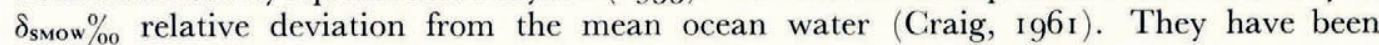
corrected for the various factors discussed by Craig (1957). The N.B.S. IA standard was used for calibration. The reproducibility of the measurements was better than $0.3 \%$. A plot of $\delta$ values against depth is presented in Figure 3. The depths of the samples were corrected for compaction by assuming a uniform compaction rate throughout the core. Since this assumption may introduce an uncertainty of the order of ${ }_{15} \mathrm{~cm}$ in the depth, a too detailed comparison of the isotopic profile with the stratigraphic profile reported in Figure 4 would be meaningless.

The $\delta$ values are seen to oscillate between $-5^{0.8}$ and $-6 \mathrm{r} .2$ (the lowest value ever recorded in natural waters). The average value over the profile is -57 . It must be very close to the lowest average $\delta$ value of precipitation that could be measured on the Earth's surface. The lowest average $\delta$ recorded until now was $-5^{\circ}$ at the South Pole (Epstein and Sharp, I959).

Although the isotopic profile cannot be accurately correlated with the stratigraphy, the isotopic highs seem to correspond to depth-hoar layers, as was observed at the South Pole (Epstein and others, 1965).

Counting the number of isotopic oscillations in such a profile involves a great deal of personal interpretation. It seems, however, that Io to I I maxima (noted "s" on Figure 3) can be clearly recognized. Assuming that each peak corresponds to one summer season, the resulting accumulation rate would be $23.5 \pm 2.4 \mathrm{~cm}_{\text {year }}^{-1}$ of snow, equivalent to $8.6 \pm 0.9$ $\mathrm{g} \mathrm{cm}^{-2}$ year $^{-1}$.

\section{Radioactive Horizon from Nuglear Explosion Debris}

The possibility that radioactive fall-out from nuclear bomb tests has formed a reference horizon of glaciological interest in the polar ice sheets was suggested by Picciotto and others (1962) and Drevinsky and others (cited in Sharp and Epstein, 1962).

From a detailed study of ${ }^{9} \mathrm{Sr}$ and gross $\beta$-activity distribution with depth, in firn samples unambiguously dated by stratigraphic studies and ${ }^{18} \mathrm{O} /{ }^{16} \mathrm{O}$ ratio variations, Picciotto and Wilgain ( $1963[\mathrm{a}]$ ) and Wilgain and others ( 1965 ) were able to show that at Base Roi Baudouin a reference level easily detectable was formed in the layer corresponding to the summer 1954-55. It is due to the sudden appearance in Antarctic precipitation of fission products released by the Castle test series in March-April i 954 . The concentration of fission products in firn was shown to start rising in late I 954 and to reach a pronounced maximum in JanuaryFebruary 1955 .

These conclusions were confirmed and extended to other Antarctic locations by Vickers ( 1963 ), Woodward ( 1964$)$ and Wilgain and others ( 1965$)$. The existence of a similar reference horizon corresponding to a slightly earlier date was also demonstrated on the Greenland ice sheet by Martell (1959) and by Crozaz and others (1966).

On both ice sheets, the $\beta$ activity due to natural radionuclides such as ${ }^{210} \mathrm{~Pb}$ and ${ }^{40} \mathrm{~K}$, was shown to be negligible in regard to the $\beta$ activity of fission products, thus enabling an easy identification of the reference level by means of gross $\beta$ activity measurements without elaborate radiochemical separations.

In order to find the depth of the radioactivity jump corresponding to about January I 955 at the Pole of Inaccessibility, gross $\beta$ activity measurements were carried out on three firn sections sampled in pit No. 1 on 29 January I $_{96} 6$ and in pits Nos. 2 and 3 in December 1965. 5 to $20 \mathrm{~cm}$ thick samples were cut out of the pit walls and were stored frozen until the moment of analysis. 
Gross $\beta$-activity measurements were carried out on $150 \mathrm{~cm}^{3}$ aliquots. Experimental procedures used for the 20 samples from pit No. I are identical to the ones described by Picciotto and Wilgain ( $\left.\mathrm{Ig}_{3}[\mathrm{~b}]\right)$. For the other samples a faster procedure based on coprecipitation of the main fission products was used; the experimental details will be given elsewhere.
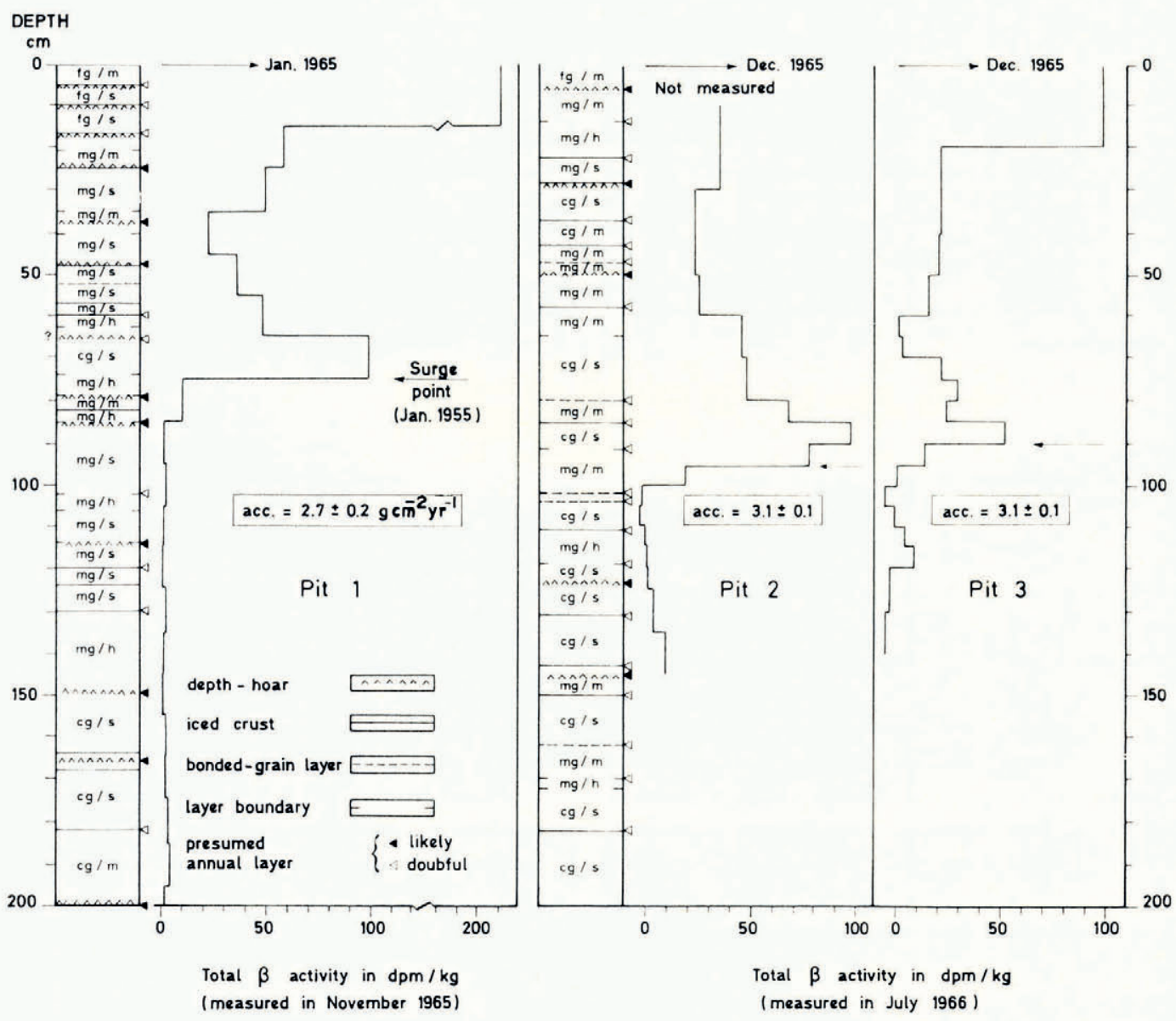

Fig. 4. Stratigraphic sequence in pits Nos, $I$ and 2. Gross $\beta$ activity as a function of depth in the firn for pits .Nos, $I, 2$ and 3

$\begin{aligned} c g & \text { coarse-grained } & h & \text { hard } \\ f g & \text { fine-grained } & m & \text { medium hard } \\ m g & \text { medium-grained } & s & \text { soft }\end{aligned}$

The results of activity measurements are shown in Figure 4 together with the corresponding stratigraphic diagrams. They are expressed rather arbitrarily in disintegrations per minute $(\mathrm{dpm})$ on the basis of a 37 per cent detection yield determined with a ${ }^{40} \mathrm{~K}$ standard. The detector background ( 0.2 counts per minute) and the reagent blank ( 0.2 counts per minute) were deduced. The standard deviation on the activity values is less than \pm ro per cent for the samples above the surge point, but it may reach $\pm 5^{\circ}$ per cent for the samples below this level, mainly in pits Nos. 2 and 3 . 
The jump of $\beta$ radioactivity is clearly marked in the three sections. Referring to the abovementioned works, there is little doubt that this jump corresponds to January 1955 with an uncertainty of \pm 2 months. Taking into account the measured densities, the accumulation

\begin{tabular}{|c|c|c|c|c|}
\hline & $\begin{array}{c}\text { Time } \\
\text { interval }\end{array}$ & $\begin{array}{c}\text { Depth of } \\
\text { surge point } \\
\mathrm{cm}\end{array}$ & $\begin{array}{l}\text { Average } \\
\text { density from } \\
\text { surface to } \\
\text { surge point }\end{array}$ & $\begin{array}{c}\text { Average } \\
\text { accumulation } \\
\mathrm{g} \mathrm{cm}^{-2} \text { year }^{-1}\end{array}$ \\
\hline Pit No. I & $\begin{array}{l}\text { January I955- } \\
\text { January } 1965\end{array}$ & $75 \pm 5$ & 0.355 & $2.66 \pm 0.18$ \\
\hline Pit No. 2 & $\begin{array}{l}\text { January 1955- } \\
\text { December } 1965\end{array}$ & $95 \pm 2.5$ & 0.355 & $3.06 \pm 0.08$ \\
\hline Pit No. 3 & $\begin{array}{l}\text { January r } 955^{-} \\
\text {December } 1965\end{array}$ & $90 \pm 2.5$ & 0.376 & $3.08 \pm 0.09$ \\
\hline \multicolumn{4}{|c|}{ Weighted average } & $3.0 \pm 0.1$ \\
\hline
\end{tabular}

rates given in Table III were obtained. The three values are in excellent agreement and result in an average accumulation rate for the time interval $1955^{-66}$ of $3.0 \pm 0.1 \mathrm{~g} \mathrm{~cm}^{-2}$ year $^{-1}$. The error represents the uncertainty in the level of the surge point due to the finite thickness of the samples.

\section{${ }^{210} \mathrm{~Pb}$ METHOD}

${ }^{210} \mathrm{~Pb}$, a natural $\beta$ emitter, is produced in the atmosphere by the decay of ${ }^{222} \mathrm{Rn}$ and is present in minute amounts in atmospheric precipitation. Owing to its 22 years half-life, it could be used for dating firn and ice samples back to approximately roo years (Goldberg, 1963; Crozaz and others, r964; Crozaz, unpublished).

Let $A_{0}=$ the ${ }^{210} \mathrm{~Pb}$ specific activity of the snow at the time of deposition,

$A_{h}=$ the ${ }^{210} \mathrm{~Pb}$ specific activity of firn or ice at a depth $h$,

$h=$ the depth from the surface, expressed in $\mathrm{g} \mathrm{cm}^{-2}$ or $\mathrm{cm}$ of water,

$a=$ the annual rate of snow accumulation in $\mathrm{g} \mathrm{cm}^{-2}$ year ${ }^{-1}$, and

$\lambda=(0.032 \pm 0.001)$ year $^{-1}$, the radioactive constant of ${ }^{2 \mathrm{IO}} \mathrm{Pb}$.

Assuming that no migration of the ${ }^{210} \mathrm{~Pb}$ takes place in the firn, as should be the case in areas of dry snow facies, one can write:

$$
A_{h}=A_{0} \mathrm{e}^{-\lambda t}
$$

where $t$ is the age of a sample from depth $h$, age being defined here as the time elapsed since deposition on the surface.

$A_{\mathrm{o}}$ is not known directly but, under the conditions that $A_{\mathrm{o}}$ and $a$ both remain constant in time, Equation ( $\mathrm{I}$ ) can be written:

$$
\ln A_{h}=\ln A_{0}-\lambda h / a \text {. }
$$

These conditions are very likely to be fullfilled, when considering average values of $A_{0}$ and $a$ over several years. A plot of $A_{h}$ versus depth in a semi-logarithmic scale should yield a straight line with a slope inversely proportional to the accumulation rate and an ordinate intercept at $A_{\mathrm{o}}$.

So far, ${ }^{210} \mathrm{~Pb}$ studies carried out in the polar ice sheets, in Antarctica (Crozaz and others, I964; Nezami and others, I 964; Picciotto and others, I964) as well as in Greenland (Goldberg, r963; Crozaz and Langway, I966), have yielded reliable accumulation-rate values.

Since the specific activity of the ${ }^{210} \mathrm{~Pb}$ in recently fallen snow is of the order of a few $\mathrm{dpm} / \mathrm{kg}$, low-level counting techniques have to be used. Owing to the very low energy of its 
$\beta$ radiation, ${ }^{210} \mathrm{~Pb}$ is generally measured by the $\beta$ activity of ${ }^{210} \mathrm{Bi}\left(T_{1}=5\right.$ days), its first daughter. It can also be measured by the $\alpha$ activity of ${ }^{210} \mathrm{Po}\left(T_{1}=\mathrm{I} 3^{8}\right.$ days $)$. This method would offer the advantage of a Io to $5^{0}$ times higher sensitivity, but so far, its use has been hampered by the lack of a suitable polonium tracer isotope thus enabling the chemical recovery yields to be checked. However, Nezami and others (I964) have obtained consistent results on samples from Terre Adélie by assuming a constant recovery yield.

The availability of the artificially made ${ }^{208} \mathrm{Po}\left(T_{1}=2.9\right.$ years; Spicer, $\left.{ }_{1}{ }_{965}\right)$ recently allowed the development of a completely reliable procedure (Crozaz and Fabri, I966) allowing the measurement of ${ }^{210} \mathrm{Po}$ activity on standard $\mathrm{I} \mathrm{m}$ long and $8 \mathrm{~cm}$ diameter cores obtained with the SIPRE hand auger.

At the Pole of Inaccessibility, ${ }^{210} \mathrm{~Pb}$ measurements were carried out by both methods $\left({ }^{210} \mathrm{Bi}\right.$ after Crozaz and others (1964) and ${ }^{210} \mathrm{Po}$ after Crozaz and Fabri (I966)) on two sets of samples collected in pit No. 2 and stored in the frozen state until the analysis.

The results are given in Table IV and Figure 5.

Table IV. ${ }^{210} \mathrm{~Pb}$ Activity as a Function of Depth

\begin{tabular}{|c|c|c|c|c|c|}
\hline \multirow[b]{2}{*}{$\begin{array}{l}\text { Depth } \\
\text { interval }\end{array}$} & \multirow[b]{2}{*}{$\begin{array}{c}\text { Equivalent } \\
\text { water depth* }\end{array}$} & \multicolumn{2}{|c|}{${ }^{210} \mathrm{Bi}$ procedure } & \multicolumn{2}{|c|}{${ }^{210} \mathrm{Po}$ procedure } \\
\hline & & $\begin{array}{l}\text { Sample } \\
\text { weight }\end{array}$ & $\begin{array}{l}{ }^{2 \mathrm{r}}{ }^{\circ} \mathrm{Pb} \\
\text { activity }\end{array}$ & $\begin{array}{l}\text { Sample } \\
\text { weight }\end{array}$ & $\begin{array}{l}{ }^{210} \mathrm{~Pb} \\
\text { activity }\end{array}$ \\
\hline $\mathrm{cm}$ & $\mathrm{cm}$ & $\mathrm{kg}$ & $\mathrm{dph} / \mathrm{kg}$ & $\mathrm{kg}$ & $\mathrm{dph} / \mathrm{kg}$ \\
\hline $0-100$ & o-37 & 3.21 & $83 \pm 9 \dagger$ & I. $6 \mathrm{I}$ & $\mathbf{r} 09 \pm \mathbf{1} 5 \dagger$ \\
\hline $100-200$ & $37-77$ & $3 \cdot 5^{\circ}$ & $66 \pm 7$ & І. 86 & $7^{8} \pm 14$ \\
\hline $200-300$ & $77^{-119}$ & 3.45 & $49 \pm 5$ & 1.8I & $50 \pm 7$ \\
\hline $300-400$ & I $19-16$ I & 6.93 & $27 \pm 3$ & 1.86 & $27 \pm 8$ \\
\hline $500-600$ & $206-25^{I}$ & - & - & 3.67 & $13=2$ \\
\hline
\end{tabular}

* From measured densities.

$\uparrow$ Standard deviation of the activity measurement.

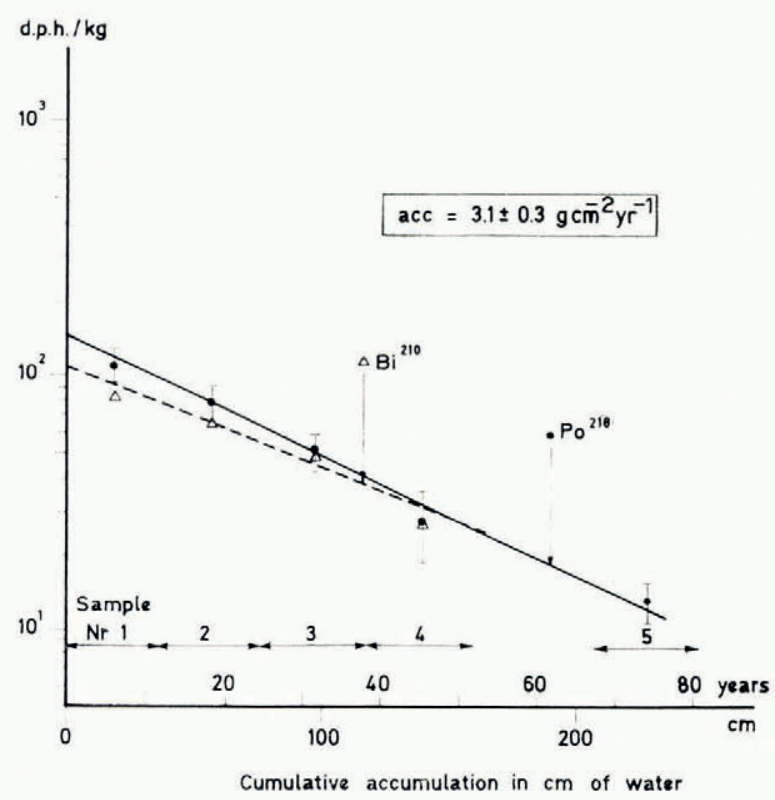

Fig. 5. ${ }^{210} \mathrm{~Pb}$ specific activity of firn versus dcpth in pit No. 2. Depth intervals of the samples are shown by horizontal arrows. The time scale on the horizontal axis is derived from the average slope of the two straight lines 
The results obtained by both methods agree within the limits of the experimental errors (Fig. 5). The resulting accumulation rates derived from equation (2) with their standard deviation are:

$$
\begin{gathered}
{ }^{210} \mathrm{Bi} \text { line }=3.5 \pm 0.5 \mathrm{~g} \mathrm{~cm}^{-2} \text { year }^{-1}, \\
{ }^{210} \mathrm{Po} \text { line }=2.9 \pm 0.3 \mathrm{~g} \mathrm{~cm}^{-2} \text { year }^{-1}, \\
\text { Weighted average }=3 . \mathrm{I} \pm 0.3 \mathrm{~g} \mathrm{~cm}^{-2} \text { year }^{-1} .
\end{gathered}
$$

\section{Conclusions}

Table $\mathrm{V}$ summarizes the results obtained by the various methods.

I. The surface measurements show definitely that the rate of snow accumulation at the U.S.S.R. station at the Pole of Relative Inaccessibility is close to $3 \mathrm{~g} \mathrm{~cm}^{-2}$ year $^{-1}$.

Table V. Annual Rate of Snow Accumulation. A Comparison of the Results

Method

December $195^{8}$ surface

Stake measurements

Pit stratigraphy

Oxygen-isotope ratios

Radioactive fall-out horizon

${ }^{210} \mathrm{~Pb}$ radioactive decay
Time interval

December 1958-30 January 1965 30 January $1965^{-1} 4$ December 1965 c. 1945 -December ${ }_{196} 6$ c. $1945-$ December 1965 January I955-December 1965 c.1886-December 1965

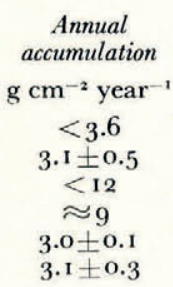

2. The II-year average deduced from fission-products activity measurements and the 80 -year average derived from the ${ }^{210} \mathrm{~Pb}$-activity distribution with depth are in excellent agreement and are consistent with the surface measurements. The validity of these methods is thus extended to the central part of the eastern Antarctic ice sheet, where the snow accumulation is at its minimum value.

3. Estimates based on firn stratigraphy and on oxygen-isotope variations are very uncertain and lead to erroneously high values. More detailed studies and better sampling procedures might improve the situation but, owing to the very small accumulation and the high probability of missing years in the firn sequence, it seems unlikely that reliable accumulation values at this point could be derived from any method based on the identification of annual layers.

4. Stratigraphic interpretations are also hampered by the rapid obliteration of the firn structures. This intense metamorphism probably results from the very low accumulation associated with very steep temperature gradients and large seasonal changes in surface temperature. It is interesting to note that this metamorphism did not result in appreciable homogenization of the ${ }^{18} \mathrm{O} /{ }^{16} \mathrm{O}$ ratios in the firn. The fluctuations, as well as the absolute values, are of the order of magnitude expected from the local climatic conditions.

In conclusion, a multi-annual average accumulation of $3 \mathrm{~g} \mathrm{~cm}^{-2}$ year-1 is firmly established for the station at the Pole of Inaccessibility.

We have no direct information on the temporal variability of the accumulation, but our results point towards it being rather constant from year to year. This is supported by the close agreement of the I $_{965}$ value with the 6 -year, I I-year and 80-year average values. Moreover, the ${ }^{210} \mathrm{~Pb}$ results (Fig. 5) indicate that the 10 -year average values did not vary by more than Io per cent over the last 80 years.

That the accumulation rate reported here is representative of a large area of central eastern Antarctica is shown by the following evidence which has in part been extracted from unpublished data of the Queen Maud Land traverse: 
I. At the U.S. "Plateau" station (lat. $79^{\circ}$ I $5^{\prime}$ S., long. $40^{\circ} 30^{\prime}$ E., elevation $3625 \mathrm{~m}$ ) the gross $\beta$-activity profile (Fig. 6) gives an average annual accumulation for the interval 1955-66 of $2.8 \pm 0.2 \mathrm{~g} \mathrm{~cm}^{-2}$ year $^{-1}$.
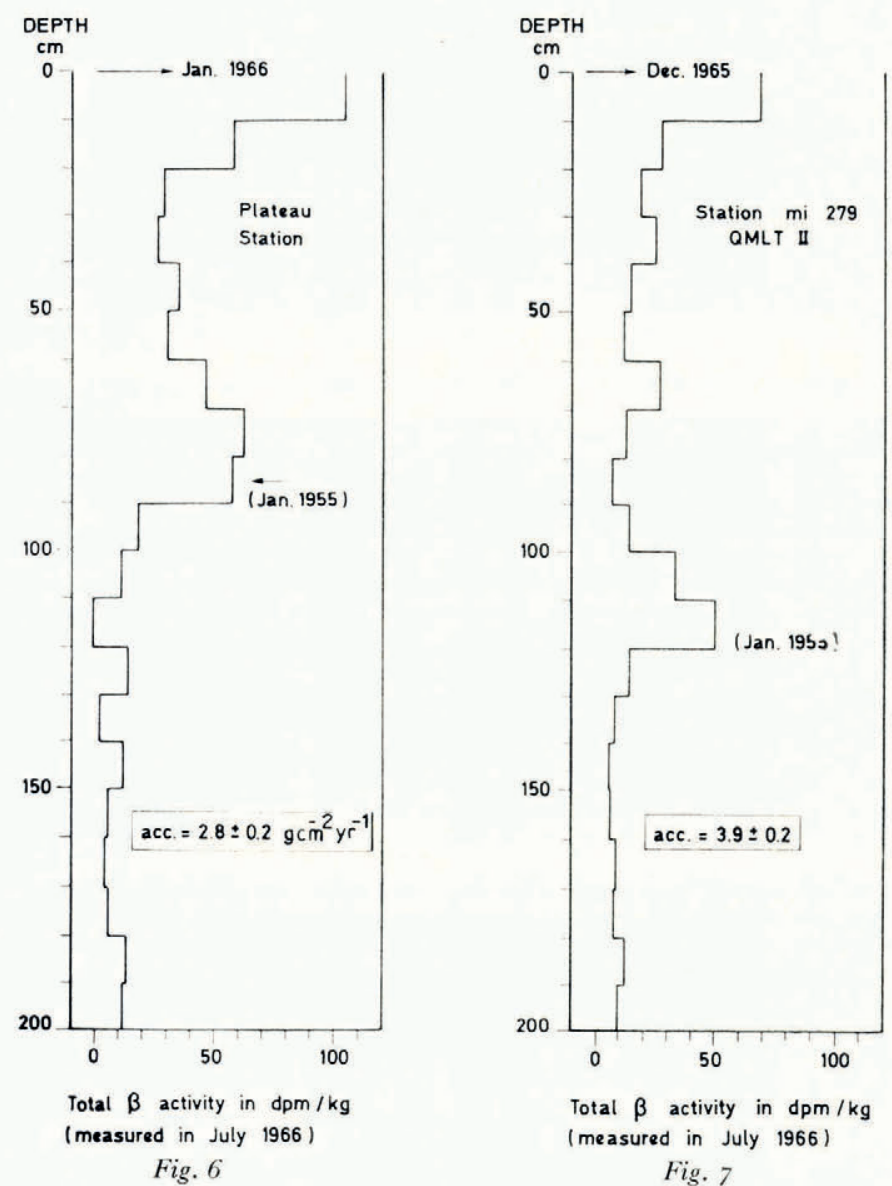

Fig. 6. Gross $\beta$ activity as a function of depth at "Plateau" station

Fig. 7. Gross $\beta$ activity as a function of depth at station mile 279 of Queen Maud Land traverse II

2. At the station mile 279 of the QMLT II (lat. $82^{\circ} 52^{\prime} \mathrm{S}$., long. $18^{\circ} 10^{\prime}$ E., elevation $26 \mathrm{I} 0 \mathrm{~m}$ ), the same method (Fig. 7) gives an I I-year average accumulation of $3.9 \pm 0.2$ $\mathrm{g} \mathrm{cm}^{-2}$ year $^{-1}$.

3. At the U.S.S.R. station of Vostok (lat. $78^{\circ} 28^{\prime}$ S., long. Io6 ${ }^{\circ} 5^{\prime}$ E., elevation $3490 \mathrm{~m}$ ), surface measurements in $195^{8}$ indicate an accumulation of the order of $3 \mathrm{~g} \mathrm{~cm}^{-2}$ year $^{-1}$ (Kotlyakov, 196r).

\section{Acknowledgements}

Financial and logistic support for this work was provided by the U.S. Antarctic Research Program, National Science Foundation, through N.S.F. grants to The Ohio State University, and to the Université Libre de Bruxelles. Task Force 43 of the U.S. Navy provided invaluable logistic support in the field operations. 
Financial support for the laboratory investigations was also provided by the Belgian Institut Interuniversitaire des Sciences Nucléaires and Fonds de la Recherche Collective Fondamentale (project 243).

We thank C. Weyers and A. Giuliani for their technical assistance in the laboratory. The field assistance of Robert Behling was highly appreciated.

\section{MS. received 7 April 1967}

\section{REFERENGES}

Benson, C. S. 1962. Stratigraphic studies in the snow and firn of the Greenland ice sheet. U.S. Snow, Ice and Permafrost Research Establishment. Research Report 70.

Botter, R., and others. 1960. Sur la teneur en deutérium des précipitations en Terre de Victoria, Antarctique, par R. Botter, C. Lorius, G. Nief. Comptes Rendus Hebdomadaires des Séances de l'Académie des Sciences (Paris), Tom. 251 , No. 4, p. $573-75$.

Craig, H. 1957. Isotopic standards for carbon and oxygen and correction factors for mass spectrometric analysis of carbon dioxide. Geochimica et Cosmochimica Acta, Vol. 12, Nos. 1-2, p. 133-49.

Craig, H. 1961. Standard for reporting concentrations of deuterium and oxygen-18 in natural waters. Science, Vol. 133 , No. 3467 , p. $1833-34$.

Crozaz, G. Unpublished. Mise au point d'une méthode de datation des glaciers basée sur la radioactivité du plomb-2 10. [Thesis, Université Libre de Bruxelles, 1967.]

Crozaz, G., and Fabri, P. 1966. Mesure du polonium à l'échelle de $10^{-13}$ curie, traçage par le ${ }^{208}$ Po et application à la chronologie des glaces. Earth and Planetary Science Letters, Vol, i, No. 6, p. 446-48.

Crozaz, G., and Langway, C. C., jr. 1966. Dating Greenland firn-ice cores with ${ }^{210}$ Pb. Earth and Planetary Science Letters, Vol. 1, No. 4, p. 194-96.

Crozaz, G., and others. 1964 . Antarctic snow chronology with ${ }^{210} \mathrm{~Pb}$, by G. Crozaz, E. Picciotto and W. de Breuck. Journal of Geophysical Research, Vol. 69, No. 12, p. 2597-604.

Crozaz, G., and others. 1966. Artificial radioactivity reference horizons in Greenland firn, by G. Crozaz, C. C. Langway, Jr., and E. Picciotto. Earth and Planetary Science Letters, Vol. I, No. I, p. 42-48.

Dansgaard, W. 1954. The Or8 abundance in fresh water. Geochimica et Cosmochimica Acta, Vol. 6, Nos. 5-6, p. $24 \mathrm{I}-60$.

Dansgaard, W. 1964. Stable isotopes in precipitations. Tellus, Vol. 16, No. 4, p. 436-68.

Epstein, S. 1956. Variations of the $\mathrm{O}^{18} 8 \mathrm{O}^{16}$ ratios of fresh waters and ice. (In Nuclear processes in geologic settings. Proceedings of the second conference, Pennsylvania State University, Sept. 8-10, 1955, p. 20-28. (National Academy of Sciences - National Research Council Publication 400, Nuclear Science Series, Report No. 19.))

Epstein, S., and Mayeda, T. 1953. Variation of $\mathrm{O}^{18}$ content of water from natural sources. Geochimica et Cosmochimica Acta, Vol. 4, No. 5, p. 21 3-24.

Epstein, S., and Sharp, R. P. 1959. Oxygen isotope studies. Transactions. American Geophysical Union, Vol. 40, No. I, p. $8 \mathrm{I}-84$.

Epstein, S., and others. 1963. Oxygen-isotope ratios in Antarctic snow, firn and ice, by S. Epstein, R. P. Sharp and I. Goddard. Journal of Geology, Vol. 71, No. 6, p. 698-720.

Epstein, S., and others. 1965. Six-year record of oxygen and hydrogen isotope variations in South Pole firn, by S. Epstein, R. P. Sharp and A. J. Gow. Journal of Geophysical Research, Vol. 7o, No. 8, p. 18o9-14.

Friedman, I., and others. 1964. The variation of the deuterium content of natural waters in the hydrologic cycle, by I. Friedman, A. C. Redfield, B. Schoen and J. Harris. Reviews of Geophysics, Vol. 2, No. 1, p. 177-224.

Giovinetto, M. B. 1960. Glaciology report for 1958 , South Pole station. Ohio State University Research Foundation. Report 825-2-IV.

Giovinetto, M. B., and Schwerdtfeger, W. 1966. Analysis of a 200-year snow accumulation series from the South Pole. Archiv für Meteorologie, Geophysik und Bioklimatologie, Ser. A, Bd. 15, Ht. 2, p. 227-50.

Goldberg, E. D. 1963. Geochronology with lead-2 10. (In Radioactive dating. Proceedings of the svmposium on radioactive dating held by the International Atomic Energy Agency in co-operation with the Joint Commission on Applied Radioactivity (ICSU) in Athens, 19-23 November 1962. Vienna, International Atomic Energy Agency, p. 121-30.)

Gonfiantini, R., and Picciotto, E. 1959. Oxygen isotope variations in Antarctic snow samples. Nature, Vol. 184, No. 4698 , p. $1557-58$.

Gonfiantini, R., and others. 1963 . Snow stratigraphy and oxygen isotope variations in the glaciological pit of King Baudouin station, Queen Maud Land, Antarctica, by R. Gonfiantini, V. Togliatti, E. Tongiorgi, W. de Breuck and E. Picciotto. Journal of Geophysical Research, Vol. 68, No. 13, p. 3791-98.

Gow, A. J. 1965. On the accumulation and seasonal stratification of snow at the South Pole. Journal of Glaciology, Vol. 5 , No. 4 o, p. $467-77$.

Kapitsa, A. P. 1964. Priroda tsentral'noy Antarktidy [The nature of central Antarctica]. Priroda [Nature], 1964, No. 9 , p. $46-56$.

Kotlyakov, V. M. ${ }_{1961}$. Skhema intensivnosti pitaniya lednikovogo pokrova Antarktidy [Rate of accumulation of the Antarctic ice cap]. Informatsionnyy Byulleten' Sovetskoy' Antarkticheskoy Ekspeditsii [Information Bulletin of the Soviet Antarctic Expedition], No. 25, p. 19-22.

Langway, C. C., jr. 1965 . Chemical composition studies in stratigraphic analysis of a deep ice core from Greenland. U.S. Cold Regions Research and Engineering Laboratory. Research Report 77. 
Lorius, C. 1961. Concentration en deutérium des couches de névé dans l'Antarctique. Annales de Géophysique, Tom. ${ }_{17}$, No. 4 , p. 378-87.

Lorius, C. 1963. Le deutérium: possibilités d'application aux problèmes de recherche concernant la neige, le névé et la glace dans l'Antarctique. CNFRA (Comité National Français des Recherches Antarctiques), No. 8.

Martell, E. A. 1959. Atmospheric aspects of strontium-9o fallout. Science, Vol. 129, No. 3357, p. 1 $197-1206$.

Nezami, M., and others. I964. Mesure du taux d'accumulation de la neige au bord du continent antarctique par la méthode du plomb 2 Io, par M. Nezami, G. Lambert, C. Lorius et J. Labeyrie. Comptes Rendus Hebdomadaires des Séances de l'Académie des Sciences (Paris), Tom. 259, No. 19, p. 3319-22.

Picciotto, E., and Wilgain, S. E. 1963[a]. Fission products in Antarctic snow: a reference level for measuring accumulation. Fournal of Geophysical Research, Vol. 68, No. 2 I, p. 5965-72.

Picciotto, E., and Wilgain, S. E. 1963[b]. Produits de fission dans les neiges antarctiques: un horizon-repère pour les mesures d'accumulation. Contrat EURATOM-U.L.B.-C.N.E.N. or3-6I-7 AGEC, Rapport interne, Université Libre de Bruxelles.

Picciotto, E., and others. I960. Isotopic composition and temperature of formation of Antarctic snows, by E. Picciotto, X. de Maere [d'Aertrycke] and I. Friedman. Nature, Vol. 187, No. 4740, p. 857-59.

Picciotto, E., and others. 1962. Radioactivité de l'air dans l'Antarctique en 1958 et profil radioactif entre $60^{\circ} \mathrm{N}$ et $70^{\circ} \mathrm{S}$, par E. Picciotto, S. [E.] Wilgain, P. Kipfer et R. Boulenger. (In Radioisotopes in the physical sciences and industry. Vol. 1 . Proceedings of the conference on the use of radioisotopes in the physical sciences and industry held by the International Atomic Energy Agency, with the co-operation of the United Nations Educational, Scientific and Cultural Organization, at Copenhagen, 6-17 September 1960. Vienna, International Atomic Energy Agency, p. 45-56.)

Picciotto, E., and others. I964. Rate of accumulation of snow at the South Pole as determined by radioactive measurements, by E. Picciotto, G. Crozaz and W. de Breuck. Nature, Vol. 203, No. 4943, p. 393-94.

Schytt, V. 1958. Glaciology. II. Snow studies at Maudheim. Norwegian-British-Swedish Antarctic Expedition, 1949-52. Scientific Results, Vol. 4, A.

Sharp, R. P., and Epstein, S. 1962. Comments on annual rates of accumulation in West Antarctica. Union Géodésique et Géophysique Internationale. Association Internationale d'Hydrologie Scientifique. Commission des Neiges et Glaces. Colloque d'Obergurgl, $10-9-18-9$ I 962 , p. 273-85.

Spicer, G. S. 1965. The determination of lead-2 10 and polonium-2 1o in air filters. [U.K.] Atomic Energy Research Establishment, AM-102.

Vickers, W. W. 1963 . Geochemical dating techniques applied to Antarctic snow samples. Union Géodésique et Géophysique Internationale. Association Internationale d'Hydrologie Scientifique. Assemblée générale de Berkeley, 19-83I-8 rg63. Commission des Neiges et des Glaces, p. 199-2 I 5.

Wilgain, S. E., and others. 1965. Strontium-9o fallout in Antarctica, by S. E. Wilgain, E. Picciotto, W. de Breuck. Journal of Geophysical Research, Vol. 70, No. 24, p. 6023-32.

Woodward, R. N. 1964 . Strontium-9o and cæesium-137 in Antarctic snows. Nature, Vol. 204, No. 4965, p. 129 I. 